\title{
Concentration of heavy metals in condensed atmospheric water vapor at three Mexican localities
}

\author{
Ana Laura BAUTISTA-OLIVAS, ${ }^{1 *}$ Fidencio CRUZ-BAUTISTA, ${ }^{1}$ Clara Rosalía ÁLVAREZ-CHÁVEZ, ${ }^{2}$ \\ Andrea Guadalupe ZAVALA-REYNA, ${ }^{3}$ Luz Amelia SÁNCHEZ-LANDERO ${ }^{4}$ and Juana ALVARADO-IBARRA ${ }^{5}$ \\ ${ }^{1}$ Departamento de Agricultura y Ganadería, Universidad de Sonora \\ ${ }^{2}$ Departamento de Ciencias Químico-Biológicas, Universidad de Sonora \\ ${ }^{3}$ Departamento de Ingeníeria Industrial, Universidad de Sonora \\ ${ }^{4}$ Facultad de Agronomía, Universidad Veracruzana \\ ${ }^{5}$ Departamento de Investigación en Polimeros y Materiales, Universidad de Sonora \\ *Corresponding author; email: ana.bautista@guayacan.uson.mx
}

Received: November 4, 2016; accepted: April 26, 2017

\begin{abstract}
RESUMEN
La condensación de agua es una técnica que puede aprovecharse para mitigar la escasez de agua para consumo humano. Sin embargo, es necesario garantizar que tenga la calidad suficiente para utilizarse sin comprometer la salud del consumidor. En este trabajo se cuantificaron los elementos traza como $\mathrm{As}, \mathrm{Ba}, \mathrm{Cu}, \mathrm{Cd}, \mathrm{Cr}, \mathrm{Fe}$, $\mathrm{Hg}, \mathrm{Mn}, \mathrm{Pb}$ y $\mathrm{Zn}$, el potencial hidrógeno $(\mathrm{pH})$ y la conductividad eléctrica (CE), en el agua condensada de la atmósfera en tres localidades de México. El agua se condensó con un prototipo que induce el punto de rocío a partir de la humedad atmosférica. Se obtuvieron un total de 108 muestras en los tres sitios de estudio, en dos épocas del año (lluvias y secas) y en dos turnos (diurno y nocturno). Los metales pesados se analizaron con un espectrofotómetro de plasma acoplado inductivamente (ICP-MS, por sus siglas en ingles). El pH y la $\mathrm{CE}$ se midieron con un potenciómetro/conductímetro. Se encontraron $\mathrm{Pb}$, Fe y Cd en $91.66 \%, 58.33 \%$ y 33\% de las muestras, respectivamente, en concentraciones que superan la norma de la Organización Mundial de la Salud (OMS) para agua destinada a consumo humano. El pH y la CE están dentro de los límites establecidos por el Departamento de Asuntos del Agua de Namibia. El contenido de metales traza en el agua condensada de la atmósfera cumple con los límites permisibles señalados por la OMS para la mayoría de los elementos analizados en este trabajo.
\end{abstract}

\begin{abstract}
The condensation of water vapor is a very useful technique in mitigating the scarcity of water resources for human consumption; however, the quality of this water must meet the highest standards to avoid becoming a health hazard. The present study quantifies trace elements such as $\mathrm{As}, \mathrm{Ba}, \mathrm{Cu}, \mathrm{Cd}, \mathrm{Cr}, \mathrm{Fe}, \mathrm{Hg}, \mathrm{Mn}, \mathrm{Pb}$, and $\mathrm{Zn}$, as well as $\mathrm{pH}$ and electrical conductivity (EC), in condensed atmospheric water vapor at three localities in Mexico. Atmospheric water vapor was condensed with an atmospheric water generator prototype. A total of 108 samples were obtained from three survey sites over the course of two seasons (wet and dry) during day/night shifts. The concentration of heavy metals was analyzed using inductively coupled plasma mass spectrometry. The $\mathrm{pH}$ and $\mathrm{EC}$ parameters were measured with a potentiometer/conductometer. We found $\mathrm{Pb}, \mathrm{Fe}$, and $\mathrm{Cd}$ in $91.66,58.33$, and $33 \%$ of the samples, respectively, at concentrations exceeding those permitted by the World Health Organization (WHO) for water intended for human consumption. Both $\mathrm{pH}$ and EC were within the limits established by the Department of Water Affairs of Namibia. The concentrations of trace metals in condensed atmospheric water vapor samples were within the maximum permissible limits determined by WHO for most elements analyzed in this study.
\end{abstract}

Keywords: Trace ions, atmospheric water vapor, active condenser, water quality, hygroscopicity. 


\section{Introduction}

Atmospheric water vapor is a natural resource currently used as a complementary water supply for domestic purposes in countries such as Chile, the Canary Islands, and Nicaragua, among others (Schemenauer and Cereceda, 1992). However, the quality of the condensed water is variable and depends on the chemical composition of the air. Due to the high dissolving capacity and combination properties of water, the ensemble of inorganic and organic substances, such as gases, aerosols, dust, salts, bacteria, and viruses, present in the atmosphere naturally incorporates into water (Ramos et al., 2003).

Igawa et al. (1998) state that the ion concentration in atmospheric water vapor depends on air pollution, which is influenced by both natural and industrial sources producing gases and liquid or solid particles in suspension that are transported by the wind (Conner et al., 2001). Schemenauer and Cereceda (1992), Muselli et al. (2006), and Gandhidasan and Abualhamayel (2007) note that in addition to the aforementioned factors, ion concentration depends on the material upon which this water vapor condenses. Jacob et al. (1985) and Fuzzi et al. (1984) declared that air temperature, solar radiation, and altitude have great influence on the concentration of chemical compounds contained in atmospheric water vapor.

Heavy metals such as $\mathrm{As}, \mathrm{Cd}$, and $\mathrm{Pb}$ are often present in the air, especially in industrialized cities. The concentration of $\mathrm{Pb}$, one of the major pollutants in the Valley of Mexico, has declined since the mid1990s, when its use in fossil fuels was discontinued (Fenn et al., 2002; Escobedo and Chacalo, 2008). Heavy metals are released in large quantities to the environment, primarily into the atmosphere, and transported to terrestrial ecosystems by rain, snow, dry deposition, and atmospheric flux (Lindberg, 1982; Kim et al., 2000). Heavy metals have been shown to cause severe damage even in low concentrations; therefore, environmental and health protection authorities worldwide have made great attempts to minimize human exposure, particularly of children, to these hazardous elements (ATSDR, 2007).

The biggest issue concerning pollution containing toxic metals is the variety of contributing factors, among them, the quantity and variety of emitting sources. The presence in the atmosphere of elements such as As, Mn, Hg, and Se derives, mostly, from natural sources; however, at a regional level, anthropogenic sources may contribute significantly to the emission of heavy metals at the local scale (Wiersman and Davidson, 1986; Wood and Goldberg, 1988; Tucker, 1991; Kabatas-Pendias and Pendias, 1992). Heavy metal ions, present in the air, concentrate in water droplets as well as in rainwater (Nriagu, 1996; Padilla, 1989; Igawa et al., 1998).

Therefore, the aim of this study was to assess the concentration of trace ions, $\mathrm{pH}$, and EC in condensed atmospheric water vapor from three Mexican localities: San Felipe Hidalgo, Tlaxcala; Huichapan, Hidalgo; and Mexico City. We sought to establish a frame of reference for the quality of water obtained by the condensation of atmospheric water vapor in these zones and to determine its potential for human consumption.

\section{Methods}

\subsection{Study area}

The present study surveyed three different sites (Fig. 1). The first of these sites was the ecotourism park Piedra Canteada, located in the town of San Felipe Hidalgo, municipality of Nanacamilpa, Tlaxcala, with geographical coordinates $19^{\circ} 28^{\prime}-19^{\circ} 26^{\prime} \mathrm{N}$, $98^{\circ} 36^{\prime}-98^{\circ} 35^{\prime} \mathrm{W}$. This area has an altitude ranging between 2700 and 3100 masl. It has a temperate, sub-humid climate with rainfall in summer and an annual precipitation average of 700-1000 $\mathrm{mm}$. The annual average temperature ranges between 18 and $24{ }^{\circ} \mathrm{C}$, with variations ranging from $0.5^{\circ} \mathrm{C}$ to $24.6^{\circ} \mathrm{C}$ (INAFED, 2016a).

The second site is located in Huichapan, Hidalgo. This site is found within the central sector of the trans-Mexican volcanic belt, $110 \mathrm{~km}$ northwest of Mexico City. Its geographical coordinates are $20^{\circ} 22^{\prime}$ $06.31^{\prime \prime} \mathrm{N}, 99^{\circ} 39^{\prime} 00.56^{\prime \prime} \mathrm{W}$, with an altitude of 2131 masl. The area is characterized by a cool temperate climate with an annual average temperature of $16^{\circ} \mathrm{C}$ and an average precipitation of $437 \mathrm{~mm} /$ year, primarily from May to September. The site is also characterized by being located on a plain (INAFED, 2016b).

The third site is located within the Cuauhtémoc borough in Mexico City, with coordinates $19^{\circ} 24^{\prime}$ 26.21" N, 99 $09^{\circ} 36.31^{\prime \prime} \mathrm{W}$ and an altitude of 2236 masl. This site is characterized as being an urban area 


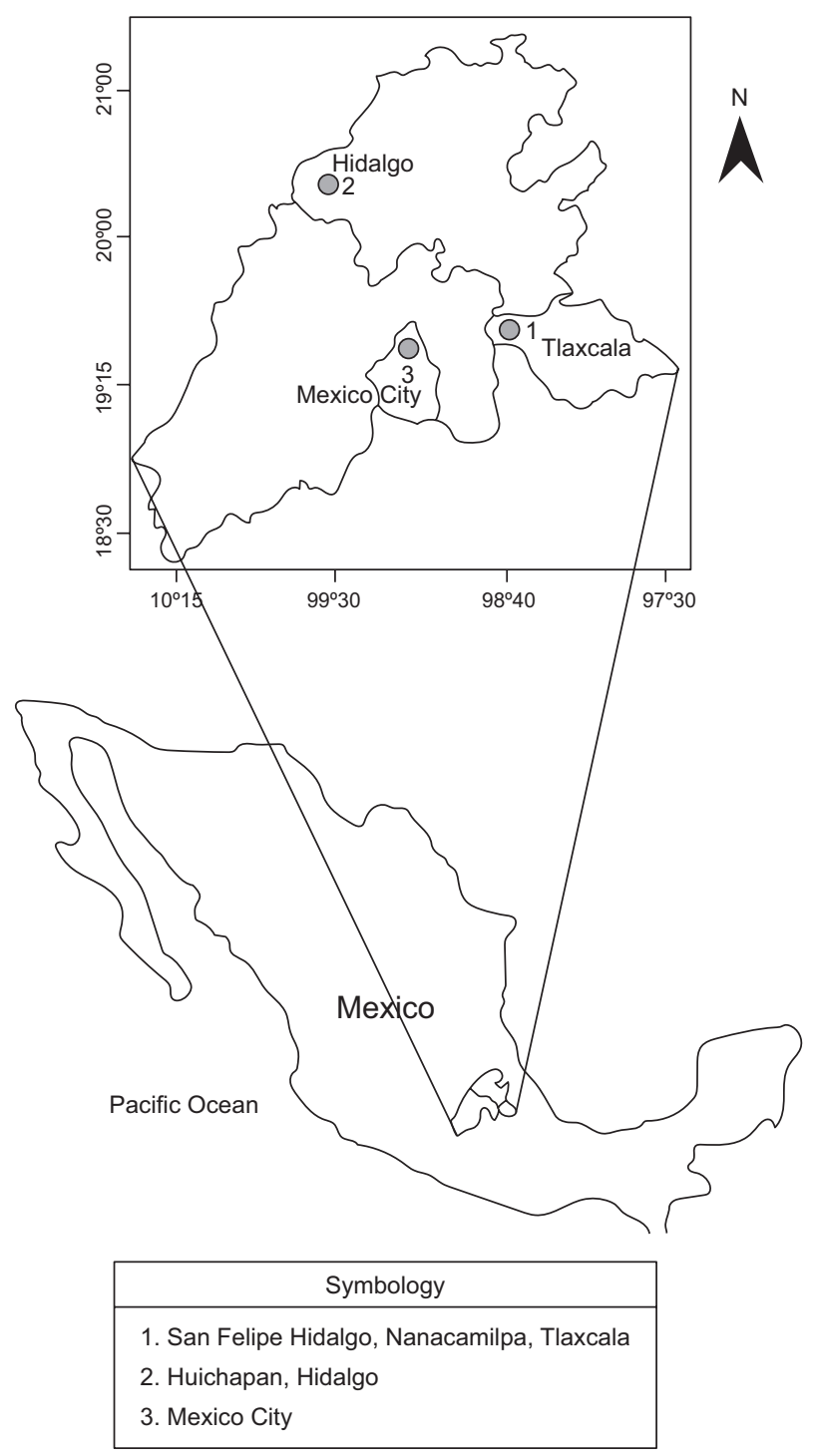

Fig. 1. Location of the study sites.

surrounded by mountains of volcanic origin. The annual average temperature is $15^{\circ} \mathrm{C}$, and the annual average precipitation is $1250 \mathrm{~mm}$ (INAFED, 2016c).

\subsection{Sample collection}

Atmospheric water was collected using an atmospheric water generator prototype (Higroiman, version CP-HI-04), which captures and condenses air humidity. This prototype is a variant of the CP-HI-03 model proposed by Bautista-Olivas et al. (2011). The CP-HI-04 incorporates a fan that injects air into a storage tank, and the dew point is induced by a cooling system working in tandem. The condensation capacity of the CP-HI-04 is $\sim 2 \mathrm{~L}$ of water in $24 \mathrm{~h}$. The device was washed with twice-distilled water to avoid potential sources of contamination by dry deposition.

\subsection{Survey}

The study was conducted at three locations over two seasons (August-September 2011 for the wet season and December-January 2011-2012 for the dry season) during day/night shifts: 8:00 to 20:00 and 20:30 to 7:30 LT. Samples were collected for each shift, season, and site to analyze the concentration of trace ions, 108 samples in total.

\subsection{Sample handling and preservation}

The collected water samples were stored in 100-ml high-density polypropylene containers. Following the guidelines of EPA (1983) and APHA (1995), the samples were preserved in an icebox and transferred to our laboratory. Each sample was aliquoted in two equal volumes; one aliquot was mixed with concentrated nitric acid $(\mathrm{pH}<2)$ to avoid the precipitation of trace elements, followed by corresponding analysis according to EPA norms (1983). The second aliquot was used for $\mathrm{pH}$ and $\mathrm{EC}$ analyses.

\subsection{Heavy metal concentration assessment}

The presence of trace ions in the samples was analyzed in total and their concentrations were determined using an inductively coupled plasma mass spectrometer (ICP-MS) (Perkin-Elmer 5300 Optima).

Twice-distilled water was used as blanks to ensure the reliability of trace ion concentration analysis. The $\mathrm{pH}$ and $\mathrm{EC}$ analyses were performed using a potentiometer/conductometer (Beckman, model Hoffman Pinther Boswork). All analyses were performed in the environmental sciences laboratory of the Colegio de Postgraduados, Campus Montecillo.

\subsection{Quality control}

To guarantee the efficiency of the ICP-MS calibration during trace ion concentration analysis, control samples were considered as a standard, obtaining the following recovery values: $\mathrm{Al}, 99.4 \%$; As, 98.27\%; Ba, 98.7\%; Cd, 100.35\%; Cr, 107.29\%; Cu, 99.25\%; Fe, 106.29\%; Hg, 106.15\%; Mn, 96.4\%; Pb, 98.83\%; and $\mathrm{Zn}, 98.21 \%$. These percentages fall within the $\pm 10 \%$ range, indicating no interference in the evaluation of these elements in our atmospheric water 
samples, which were analyzed according to EPA (1996) norms. In addition, we used the high-purity standards of the National Institute of Standards and Technology of the United States to construct the calibration curves for ICP-MS analyses.

\subsection{Data analysis}

The obtained values for the concentrations of heavy metals were analyzed by factorial analysis of variance (ANOVA) with three factors: (1) study site, three levels (San Felipe Hidalgo, Tlaxcala; Huichapan, Hidalgo; and Mexico City); (2) season, two levels (wet and dry); and (3) day/night shifts (diurnal/nocturnal). The general model is as follows:

$y_{i j k l}=\mu+\alpha_{i}+\beta_{j}+g_{k}+(\alpha \beta)_{i j}+(\alpha g)_{i k}+(\beta g)_{j k}+$ $(\alpha \beta g)_{i j k}+e_{i j k l}$

where $\mu=$ average; $\alpha i=$ site; $\beta j=$ season; $g_{k}=$ day/ night shift; $i=$ effect of $i$ level site; $j=$ effect of $j$ level season; $k=$ effect of $k$ level day/night shift; $(\alpha \beta)_{i j}=$ effect of the interaction between $i$ level site and $j$ level season; $(\alpha g)_{i k}=$ effect of the interaction between $i$ level site and $k$ level day/night shift; $(\beta g)_{j k}=$ effect of the interaction between $j$ level season and $k$ level day/night shift; $(\alpha \beta g)_{i j k}=$ effect of the interaction between $i$ level site, $j$ level season, and $k$ level day/ night shift; and $e_{i j k l}=$ standard error.

The terms of this technique are justified by the central limit theorem; homoscedasticity was covered in every case. We used the statistical software MINIT$\mathrm{AB}^{\circledR}$ version 14 , considering a confidence value $\alpha=$ 0.05 . We tested the effects of the site and season on the concentration of trace ions in condensed atmospheric water vapor. The average mean comparison was achieved by the Tukey test, with $95 \%$ confidence. The obtained information was compared with the guidelines stipulated by WHO (1994) defining the maximum permissible limits of trace elements in water safe for human consumption.

The locations of potential contamination sources were obtained from the Directorio Estadístico de Unidades Económicas (National Statistical Directory of Economic Units) (INEGI, 2016). We considered sources that were located within a 50-km (30-mi) radius of each study site, had more than 10 workers and involved a type of industrial and economic activity such as tobacco production, tanning and leather production, oil and carbon derived production, electronic devices production, and chemical processing. Wind speed and direction were obtained from automated meteorological stations established by Conagua (2016). This information was used to produce wind rose plots with the software WRPLOT View freeware version 7 to determine wind direction and velocity.

\section{Results and discussion}

\subsection{Trace ions}

Table I shows the factorial analysis of trace ions present in condensed atmospheric water vapor from three study sites in two seasons for day/night shifts. It indicates the average concentration, standard deviation, and maximum permissible limits for drinking water (WHO, 1994).

According to the information in Table I, the elements exceeding the maximum permissible limits by the WHO (1994) are, in descending order, Fe, $\mathrm{Pb}$, and $\mathrm{Cd}$, concurring with Mat et al. (2014). The concentrations of $\mathrm{Cu}, \mathrm{Cr}, \mathrm{Mn}$, and $\mathrm{Zn}$ are below the maximum permissible limits, although significant differences were present among sites, season and shifts. Ions of Ba and As were also at concentrations less than the permissible limits established by the WHO (1994), not exhibiting significant differences among the studied factors. As ions were absent in several samples collected during the dry season in the three study sites, particularly when atmospheric water vapor condensation occurred during the nocturnal shift. Similarly, $\mathrm{Hg}$ ions were absent in samples collected during the wet season; regardless, this element exceeded the maximum permissible limits determined by the WHO (1994) in those samples where it was detected, especially during the dry season. The concentration of the analyzed ions agrees with reports by Gandhidasan and Abualhamayel (2007) for Arabia, Bautista et al. (2014) for Mexico, Patel et al. (1998) for India, Joos and Baltensperger (1991) for Switzerland, and Jacob et al. $(1985,1986)$ for the USA.

The factorial analysis indicates that both, location and season, have great influence on the concentration of $\mathrm{Fe}, \mathrm{Pb}, \mathrm{Cu}, \mathrm{Cr}, \mathrm{Mn}$, and $\mathrm{Zn}$ ions. The season (wet and dry) influence is primarily on the concentration of these elements in condensed water vapor, which demonstrate a higher concentration during the dry 


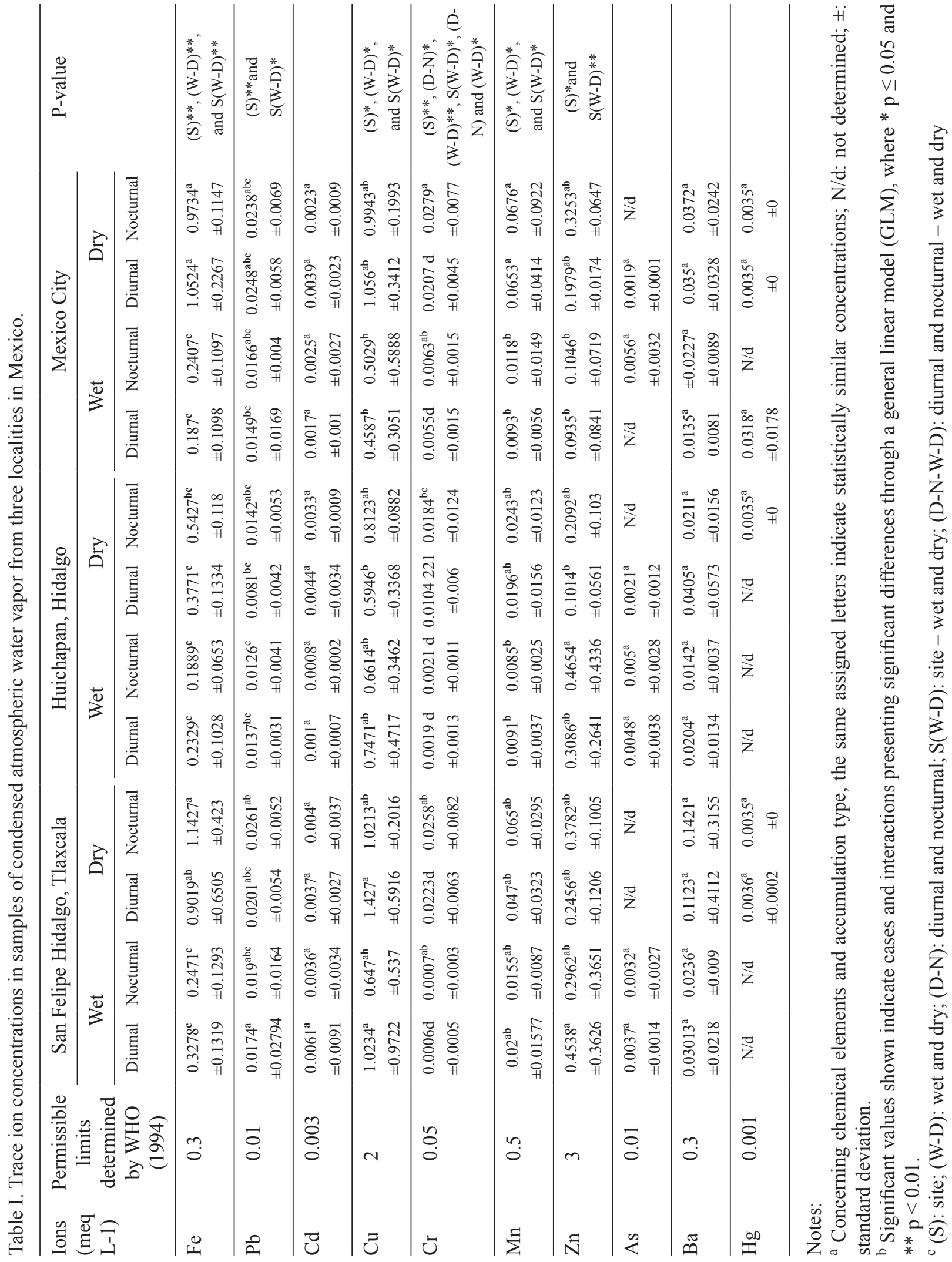


season (Table I). Trace ions of $\mathrm{Cu}$ and Fe exhibit the highest differences $(p \leq 0.05)$, primarily during the dry season, in all three of the study sites.

The highest concentration of trace metals during the dry season is attributed to the removal of ions suspended in the atmosphere by precipitation, signifying humid deposition (Duce et al., 1983). Finlayson-Pitts and Pitts (1986) add that rainfall influences the concentration of suspended particles, which is evident when comparing the months with abundant rainfall with those having little or none, therefore indicating that rainfall depurates particles suspended in the atmosphere. Duce and Hoffman (1976) concluded that the removal of suspended particles by rainfall is approximately two times higher than that by dry deposition.

The results shown in Table I indicate that the site in San Felipe Hidalgo, Tlaxcala, presented the highest concentration of trace ions in condensed atmospheric water vapor, followed by Mexico City and, lastly, the site in Huichapan Hidalgo.

The site in San Felipe Hidalgo showed higher concentrations of $\mathrm{Fe}, \mathrm{Pb}$ and $\mathrm{Cd}$ (Figs. 2, 3 and 4) in condensed atmospheric water vapor, particularly for

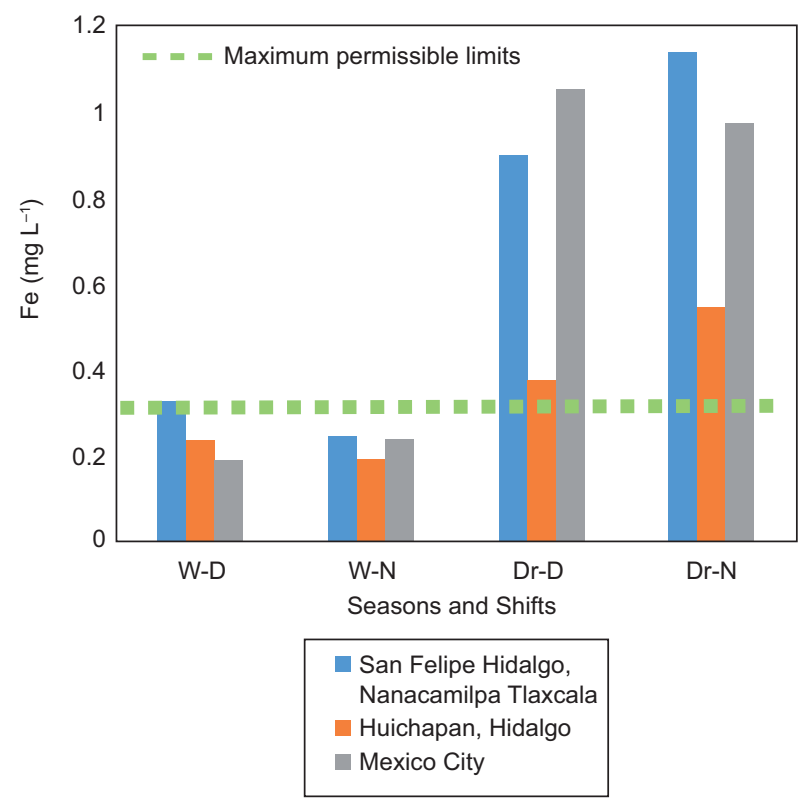

Fig. 2. Concentration of Fe ions in three study sites during wet (W) and dry (Dr) seasons for diurnal (D) and nocturnal (N) shifts. W-D = wet season, diurnal shift; $\mathrm{W}-\mathrm{N}=$ wet season, nocturnal shift; Dr-D = dry season, diurnal shift; $\mathrm{Dr}-\mathrm{N}=$ dry season, nocturnal shift.

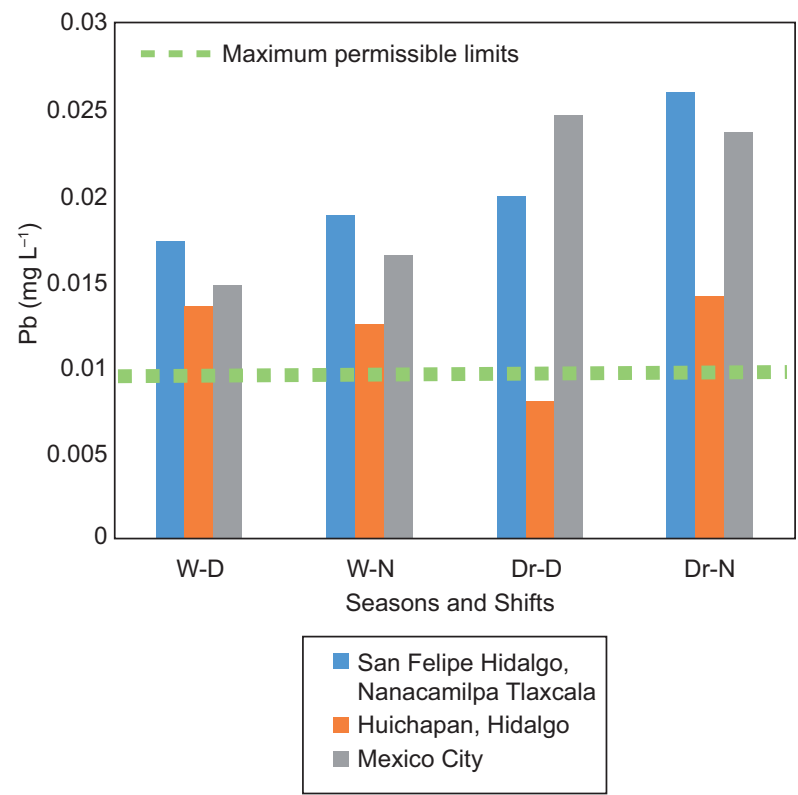

Fig. 3. Concentration of $\mathrm{Pb}$ ions in three study sites during wet (W) and dry (Dr) seasons for diurnal (D) and nocturnal (N) shifts. W-D = wet season, diurnal shift; W-N = wet season, nocturnal shift; Dr-D = dry season, diurnal shift; Dr-N $=$ dry season, nocturnal shift.

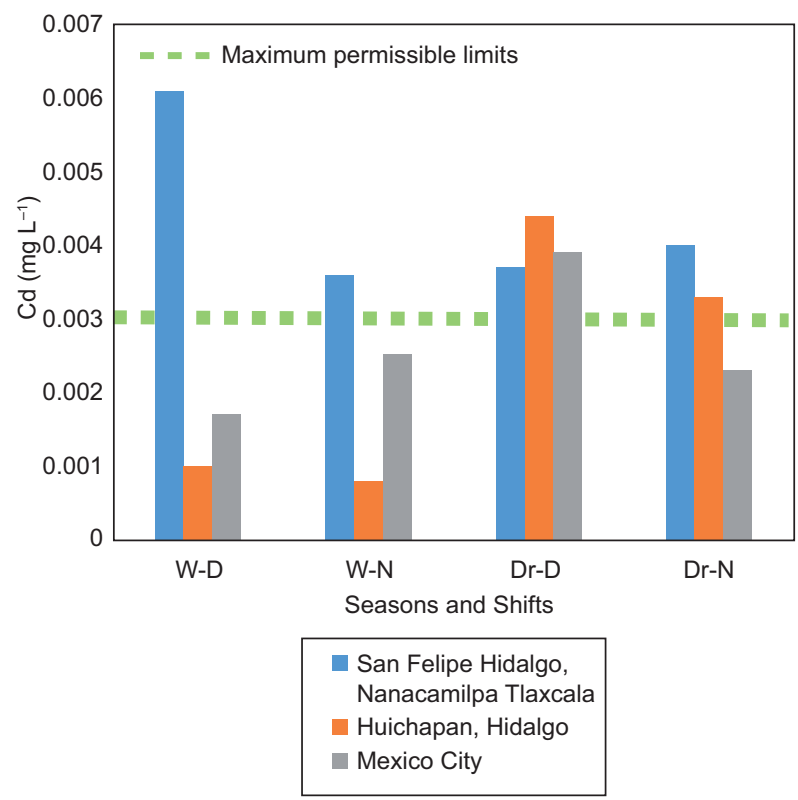

Fig. 4. Concentration of Cd ions in three study sites during wet (W) and dry (Dr) seasons for diurnal (D) and nocturnal (N) shifts. W-D = wet season, diurnal shift; W-N = wet season, nocturnal shift; Dr-D = dry season, diurnal shift; Dr-N = dry season, nocturnal shift. 
$\mathrm{Fe}$ and $\mathrm{Pb}$ during the dry season. This result draws attention because this site has been designated an ecotourism park; it is remote from city's and surrounded by forest.

The higher concentrations could be explained by the following reasons: This site has 527 factories within a 50-km radius (Fig. 5). In addition, it is located $85 \mathrm{~km}$ from the of Mexico City Metropolitan Area (MCMA), characterized by high atmospheric pollution of anthropogenic origin whose primary sources are industrial processes $(12.6 \%)$ and vehicular emissions (68\%) (Salazar et al., 1981; Jiménez, 2010).

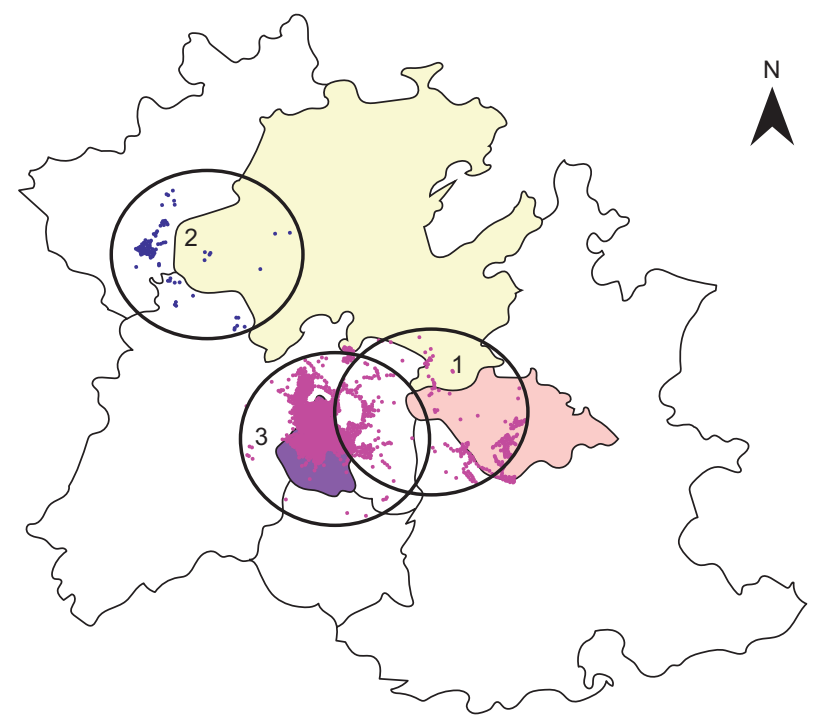

\begin{tabular}{l} 
Symbology \\
\hline 1. San Felipe Hidalgo, Nanacamilpa, Tlaxcala \\
2. Huichapan, Hidalgo \\
3. Mexico City \\
Location of various factories within a $50-\mathrm{km}$
\end{tabular}

Fig. 5. Location of various factories within a 50-km radius of the three study sites.

Fast and Zhong (1998) and Raga et al. (2001) showed that atmospheric pollution generated in the MCMA can be transported outside of the basin by wind, the southwest region being the most affected. This statement was confirmed by the wind rose graphs from Mexico City indicating a northwest to southwest wind direction, transporting the polluting particles that were suspended in the atmosphere toward this site (Fig. 6). The later statement hints at the

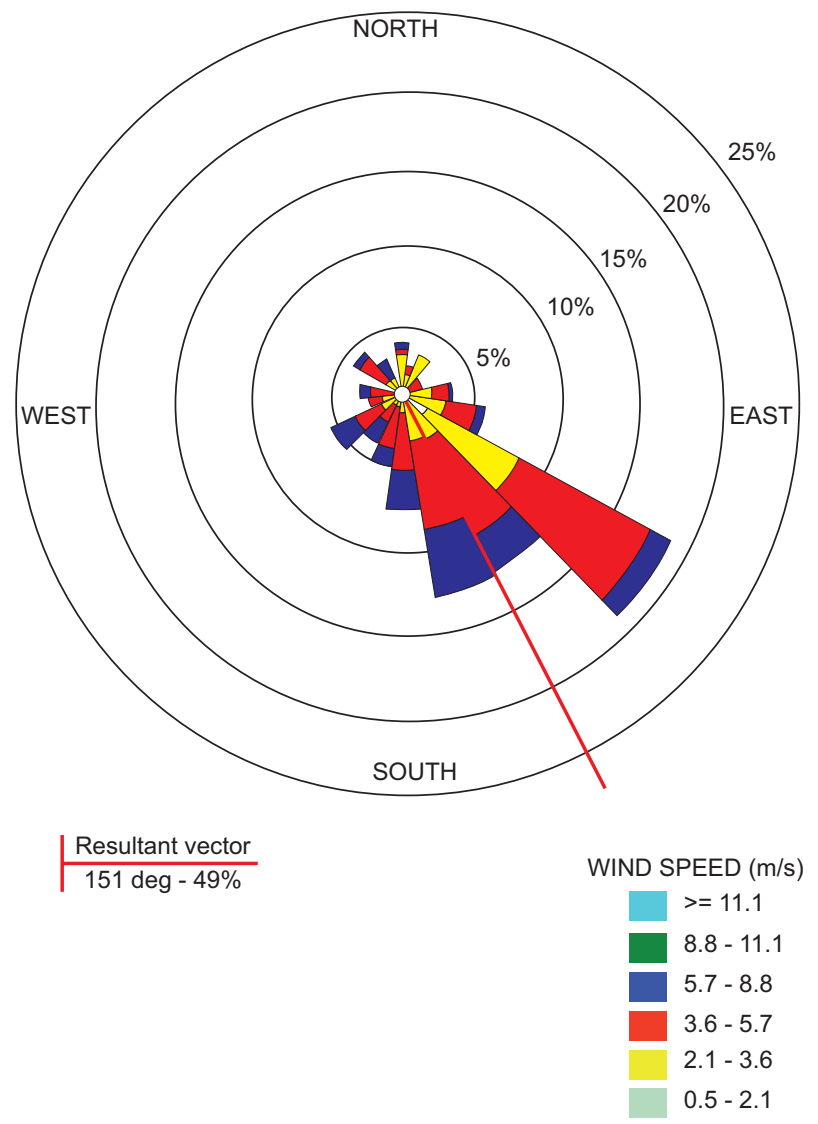

Fig. 6. Wind speed and direction in Mexico City. The red line defines the predominant vector explaining wind direction; angle predominance (\%) defines such direction. Color scale indicates wind speed.

importance of wind in the abundance of heavy metals and their variability (García et al., 2006).

However, the site is located at an altitude of 2920 masl, which is higher than Mexico City. The altitude of the site influences the oxygen content in the air, which is estimated to be $\sim 24 \%$ less than that at sea level, contributing to less efficient combustion processes (SMA, 2008).

The site in Mexico City is next discussed regarding the concentration levels of heavy metals (trace ions) in condensed atmospheric water vapor (Table I). This site is characterized as an urbanized industrial area where 100000 tons of toxic pollutants are emitted annually. Most of these pollutants are of anthropogenic origin, e.g., vehicular load (Salazar et al., 1981; SMA, 2008; Jiménez, 2010). Approximately 1912 economic units (EUs) are located within a 50$\mathrm{km}$ radius of the study site, of which the most notable 
industries include metallurgy, metallic structures, paints and coatings, as well as electronic components (Fig. 5). However, the site is also characterized by the surrounding mountains preventing an adequate dispersion of atmospheric pollutants, which remain instead within the basin. This type of complex terrain favors lines of confluence formed by the presence of anticyclonic systems in the central region of Mexico, facilitating scenarios that typically lead to a high air pollution index (Jazcilevich et al., 2002, 2005). Moreover, wind currents are modified by the presence of buildings, decreasing the wind speed over the ground surface and increasing the presence and permanence of heavy metals (Adriano, 1992; Chester et al., 1997; Halstead et al., 2000).

The site in Huichapan, Hidalgo presented lower levels of heavy metals in condensed atmospheric water vapor. This may be explained in part by the number of EUs near this location, estimated to be only 37, resulting in the lowest industrial activity of the three sites studied (Fig. 5). The northwest to southeast wind direction and the location of the industrial zone west of the county also contribute to this effect (Fig. 6). Moreover, this site is characterized by being located on a plain, where the wind flow is uninterrupted.

\section{$3.2 \mathrm{pH}$}

Another evaluated parameter in the samples of condensed atmospheric water vapor was $\mathrm{pH}$. This parameter indicates the presence of highly water-soluble ions. The results obtained for the $\mathrm{pH}$ analysis of the samples of condensed atmospheric water vapor from the three study sites are shown in Table II.

The $\mathrm{pH}$ values of the samples obtained in San Felipe Hidalgo, Nanacamilpa, Tlaxcala, were within a range of 7.15 to 7.90; the samples from Huichapan, Hidalgo presented a range from 8.08 to 8.29 ; and the samples from Mexico City presented a range from 7.82 to 8.25 . This analysis demonstrates that significant differences exist among the sites and seasons where the samples of condensed atmospheric water vapor were collected (Table II). During the dry season, a slight increment in $\mathrm{pH}$ can be observed in the study sites of San Felipe Hidalgo and Mexico City. These differences in the $\mathrm{pH}$ values of condensed atmospheric water vapor samples, among sites and seasons, are attributed to the removal of bicarbonates, chlorides, and sodium contained in the atmosphere. This removal occurs during the wet season as a result of humid deposition (Duce et al., 1983). Concerning the site in Huichapan, the $\mathrm{pH}$ values of the samples there were statistically equivalent.

Prior observations not withstanding, the $\mathrm{pH}$ values of condensed atmospheric water vapor shown in this report are neutral or alkaline due to the presence of carbonates and bicarbonates neutralizing acidity rather than to the overall concentration of trace ions. Despite the alkaline tendency of the samples during the dry season, the guidelines established by WHO (1994) are irrespectively met.

The $\mathrm{pH}$ values obtained in the analysis coincide with reports by Gandhidasan and Abualhamayel (2007) and Bautista et al. (2014) stating that the $\mathrm{pH}$ value from atmospheric water vapor is within the range of 7.23 and 8.02. However, Kulshrestha et al. (2005) report that the average $\mathrm{pH}$ value from 10 atmospheric water vapor samples obtained in northeast India was 5.6. Therefore, the differences in $\mathrm{pH}$ can be attributed to local atmospheric pollution.

Table II. $\mathrm{pH}$ of condensed atmospheric water vapor for three localities in Mexico.

\begin{tabular}{|c|c|c|c|c|}
\hline \multirow{3}{*}{ Site } & \multicolumn{2}{|c|}{ Wet } & \multicolumn{2}{|c|}{ Dry } \\
\hline & Diurnal & Nocturnal & Diurnal & Nocturnal \\
\hline & \multicolumn{4}{|c|}{$(\mathrm{pH})$} \\
\hline $\begin{array}{l}\text { San Felipe Hidalgo, } \\
\text { Nanacamilpa, Tlaxcala }\end{array}$ & $7.29 b c \pm 0.92$ & $7.15 \mathrm{c} \pm 0.98$ & $7.89 a b \pm 0.62$ & $7.90 \mathrm{ab} \pm 0.52$ \\
\hline $\begin{array}{l}\text { Huichapan, Hidalgo } \\
\text { Mexico City }\end{array}$ & $\begin{array}{c}8.29 \mathrm{a} \pm 0.48 \\
7.90 \mathrm{ab} \pm 0.57\end{array}$ & $\begin{array}{c}8.08 \mathrm{a} \pm 0.28 \\
7.82 \mathrm{abc} \pm 0.67\end{array}$ & $\begin{array}{l}8.14 \mathrm{a} \pm 0.29 \\
8.25 \mathrm{a} \pm 0.43\end{array}$ & $\begin{array}{r}8.15 \mathrm{a} \pm 0.46 \\
7.91 \mathrm{ab} \pm 0.57\end{array}$ \\
\hline
\end{tabular}

$* *$ Letters represent the result from the Tukey test; average mean values with different letters assigned are significantly different $(\mathrm{p} \leq 0.05)$. 
Table III. EC of condensed atmospheric water vapor for three localities in Mexico.

\begin{tabular}{|c|c|c|c|c|}
\hline \multirow[t]{3}{*}{ Site } & \multicolumn{2}{|c|}{ Wet } & \multicolumn{2}{|c|}{ Dry } \\
\hline & Diurnal & Nocturnal & Diurnal & Nocturnal \\
\hline & \multicolumn{4}{|c|}{$\mathrm{EC}\left(\mu \mathrm{S} \mathrm{cm}^{-1}\right)$} \\
\hline San Felipe Hidalgo, & & & & \\
\hline Nanacamilpa, Tlaxcala & $64.27 \mathrm{~d} \pm 15.23$ & $45.87 \mathrm{~d} \pm 21.2$ & $473.22 \mathrm{ab} \pm 73.42$ & $541.66 \mathrm{a} \pm 85.34$ \\
\hline Huichapan, Hidalgo & $347.34 \mathrm{bc} \pm 91.23$ & $312.13 \mathrm{c} \pm 83.2$ & $376.56 \mathrm{bc} \pm 95.24$ & $465.68 \mathrm{ab} \pm 88.21$ \\
\hline Mexico City & $287.00 \mathrm{c} \pm 87.43$ & $359.63 b c \pm 63.56$ & $529.44 \mathrm{a} \pm 70.45$ & $588.22 \mathrm{a} \pm 67.43$ \\
\hline
\end{tabular}

**Letters represent the result from the Tukey test; average mean values with different letters assigned are significantly different $(\mathrm{p} \leq 0.05)$.

\subsection{Electrical conductivity}

The electrical conductivity (EC) of water is another indicator of ion concentration (Table III). The range in EC values of condensed atmospheric water vapor samples from San Felipe Hidalgo, Tlaxcala was from 45.87 to $473.22 \mu \mathrm{S} \mathrm{cm}^{-1}$. In Huichapan, Hidalgo, the EC values ranged from 312.13 to $541.67 \mu \mathrm{S} \mathrm{cm}^{-1}$, and in Mexico City, they ranged from 287.00 to $588.22 \mu \mathrm{S} \mathrm{cm}^{-1}$.

During the dry season, the EC values of condensed atmospheric water vapor samples from San Felipe Hidalgo, Tlaxcala, Mexico City, and Huichapan, Hidalgo increased 88, 39 and 25\%, respectively. Additionally, variations from 10 to $20 \%$ were observed in the EC values obtained from the day/night shifts for each season (dry and wet).

During the wet season, the highest average EC values were observed in Mexico City $\left(360 \mu \mathrm{S} \mathrm{cm}^{-1}\right)$ and the lowest in San Felipe Hidalgo, Tlaxcala $\left(50 \mu \mathrm{S} \mathrm{cm}^{-1}\right)$. During the dry season, the highest average EC values were also observed in Mexico City $\left(580 \mu \mathrm{S} \mathrm{cm}^{-1}\right)$ and the lowest in Huichapan, Hidalgo $\left(460 \mu \mathrm{S} \mathrm{cm}^{-1}\right)$.

The increased EC values during drought are due, primarily, to a higher ion concentration in the atmosphere, unlike during the wet season where rainfall dilutes and precipitates these particles. Environmental pollution, from anthropogenic sources such as industry and vehicular load, is a contributing factor in the increase in atmospheric particles, particularly in urban and industrial zones, as shown in our report.

The comparison of the EC values of condensed atmospheric water vapor samples from the three study sites with water quality standards shows that condensed atmospheric water vapor is within the excellent quality interval according to the Department of Water Affairs of Namibia (DWA, 1998). The EC value of these samples is approximately $500 \mu \mathrm{S} \mathrm{cm}^{-1}$ during drought, the critical period for both water supply and the incidence of atmospheric pollution. Moreover, the EC values in condensed atmospheric water vapor agree with the report by Gandhidasan and Abualhamayel (2007) and other reports concerning active condensers developed by Bautista et al. (2014).

\section{Conclusions}

The concentration of trace metals in condensed atmospheric water vapor is within the maximum permissible levels determined by the WHO (1994) for most metals analyzed in this study.

The optimal site for obtaining good quality water is in Huichapan, Hidalgo. However, prior treatment of this water, such as inverse osmosis, among other methods, should be considered to reduce the content of $\mathrm{Fe}, \mathrm{Pb}$, and $\mathrm{Cd}$ ions.

The trace elements in the condensed water vapor are of anthropogenic origin, primarily attributed to industrial production and vehicular emissions. Therefore, these trace elements tend to increase significantly during the dry seasons due to wind transport and the atmospheric deposition of pollutants.

The technique of condensing atmospheric water vapor is a viable option currently being applied in several areas of the world to supplement diminishing water supplies and the availability of good quality water for human consumption.

Because there are few published reports on this topic, it is advisable to continue research efforts focused on the development and improvement of water vapor condensers, thus enabling higher yields. 


\section{Acknowledgments}

This work was made possible by the Consejo Nacional de Ciencia y Tecnología (CONACyT) and the stipendium granted to Ana Laura Bautista Olivas. Thanks also to Marcos Arévalo Godínez and Mario Vázquez García in the equipment maintenance unit of the Colegio de Postgraduados for assembling the atmospheric water generator prototype used for the condensation of water vapor. Thanks to Conagua for providing the climate data used in generating the wind analysis, and special thanks to Luis Epigenio Cruz Ayala for his great support. Finally, thanks to INEGI, especially Julián Armando Yáñez Arvizu for his invaluable help in generating the DENUEs information in the digital map.

\section{References}

Adriano D.C., 1992. Biogeochemistry of trace metal. Lewis Publishers, Boca Raton, 513 pp.

APHA, 1995. Standard methods for examination of water and wastewater. American Public Health Association, Water Pollution Control Federation, Washington D.C., $100 \mathrm{pp}$.

ATSDR, 2007. Agency for Toxic Substances and Disease Registry. Department of Health and Human Services. Available at: http:www.atsdr.cdc.gov/es/toxfaqs/ es_tfacts $13 . h t m l$.

Bautista-Olivas A.L., J.L. Tovar-Salinas, O.L. Palacios-Vélez and O.R. Mancilla-Villa, 2011. La humedad atmosférica como fuente opcional de agua para uso doméstico. Agrociencia 45, 293-301.

Bautista-Olivas A.L., J.L. Tovar-Salinas, O.R. Mancilla-Villa, H. Magdaleno Flores, C. Ramírez Ayala, R. Arteaga Ramírez and M.A Vázquez Peña, 2014. Concentración de metales traza en el agua condensada de la humedad atmosférica en el valle de México. Interciencia 39, 324-240.

Conagua, 2016. Información climática del municipio de Huichapan y la ciudad de México. Comisión Nacional del Agua, México.

Chester R., M. Mimmo and P.A. Corcoran, 1997. Rain water-aerosol trace metal relationships at Cap Ferrati: A coastal site in the western Mediterranean. Mar. Chem. 58, 298-312. doi: 10.1016/S0304-4203(97)00056-X

Conner T.L., G.A. Norris, S.L. Mathew and R.W. Williams, 2001. Individual particle analysis of indoor, outdoor, and community samples from the 1998 Baltimore particulate matter study. Atmos. Environ. 35, 3935 3946. doi: 10.1016/S1352-2310(01)00191-1

Duce A.R. and G.L. Hoffman, 1976. Atmospheric vanadium transport to the ocean. Atmos. Environ. 10, 989-996. doi: 10.1016/0004-6981(76)90207-9

Duce A.R., V.A. Mohnen, P.R. Zimmerman, D. Grosjean, W. Cautreels, R. Chatfield, R. Jaenicke, J.A. Ogree, E.D. Pellizari and G.T. Wallace, 1983. Organic material in the global troposphere. Rev. Geophys. 21, 921-952. doi: 10.1029/RG021i004p00921

DWA, 1998. Guidelines for the Evaluation of Drinking Water for Human Consumption with Regard to Chemical, Physical and Bacteriological Quality. Department of Water Affairs, Namibia.

EPA, 1983. Methods for chemical analysis of water and wastes. Environmental Protection Agency Report No. EPA-600/4-79-020, 544 pp.

EPA, 1996. Method 6010B. Inductively coupled plasma-atomic emission spectrometry. Revision 20. Environmental Protection Agency, Las Vegas, Nevada, USA.

Escobedo F. and A. Chacalo, 2008. Estimación preliminar de la descontaminación atmosférica por el arbolado urbano de la ciudad de México Interciencia 33, 29-33.

Fast J.D. and S. Zhong, 1998. Meteorological factors associated with inhomogeneous ozone concentrations within the Mexico City basin. J. Geophys. Res. 103, 927-946. doi: 10.1029/98JD01725

Fenn M. E., L.I. Bauer, C. Rodríguez and T. Hernández-Tejeda, 2002. Nitrogen and sulphur deposition in the Mexico City air basin: impacts of Forest nutrient status and nitrate levels in drainage waters. In: Urban air pollution and forests: Resources at risk in the Mexico City air basin ( Fenn de Bauer and Hernández-Tejeda,. Ecological Studies Series, vol. 156. Springer-Verlag, New York, 298-319 pp.

Finlayson-Pitts J.B. and J-R. Pitts, 1986. Atmospheric chemistry; fundamental and experimental techniques. John Willey and Sons, New York, 1098 pp.

Fuzzi S., R.A. Castillo, J.E. Jiusto and G.C. Lala, 1984. Chemical composition of radiation fog at Albany, New York and its relationship to fog microphysics. J. Geophys. Res. 85, 7159-7164. doi: 10.1029/JD089iD05p07159

Gandhidasan P. and H. Abualhamayel, 2007. Fog collection as a source of fresh water supply in the Kingdom of Saudi Arabia. Water Environ. J. 21, 19-25. doi: 10.1111/j.1747-6593.2006.00041.x 
García, R., M.C. Torres, H. Padilla, R. Belmon, E. Azpra, M. Arcega-Cabrera and A. Báez, 2006. Measurement of chemical elements in rain from Rancho Viejo, a rural wooded area in the State of Mexico, Mexico. Atmos. Environ. 40, 6088-6100.

doi: 10.1016/j.atmosenv.2006.05.048

Halstead H.J.R., R.G. Cunninguhame and K.A Hunter, 2000. Wet deposition of trace metal to a remote site in Fiordland, New Zealand. Atmos. Environ. 34, 665-676. doi: 10.1016/S1352-2310(99)00185-5

Igawa M. Y. T. Mori and H. Okochi, 1998. Fogwater chemistry at a mountainside forest and the estimation of the air pollutant deposition via fog droplets based on the atmospheric quality at the mountain base. Enviro. Sci. Technol 32, 1566-1572.

doi: $10.1021 /$ es $970213 x$

INAFED, 2016a. Enciclopedia de los municipios de México: Nanacamilpa de Mariano Arista, Tlaxcala. Instituto para el Federalismo y el Desarrollo Municipal, Secretaría de Gobernación, México. Available at: http:// inafed.gob.mx/work/enciclopedia/EMM29tlaxcala/ index.html.

INAFED, 2016b. Enciclopedia de los municipios de México: Huichapan, Hidalgo. Instituto para el Federalismo y el Desarrollo Municipal, Secretaría de Gobernación, México. Available at: http://www.inafed.gob.mx/work/ enciclopedia/EMM13hidalgo/municipios/13029a. html.

INAFED, 2016c. Enciclopedia de los municipios de México: Ciudad de México. Instituto para el Federalismo y el Desarrollo Municipal, Secretaría de Gobernación, Mexico. Available at: http://www.inafed.gob.mx/work/ enciclopedia/EMM09DF/index.html.INEGI, 2016 Directorio Estadístico de Unidades Económicas. Instituto Nacional de Estadística y Geografía, México, Available at: http://www3.inegi.org.mx/sistemas/mapa/denue/.

Jacob D.J., J.M. Waldman, J.W. Munger and M. R. Hofftmann, 1985. Chemical composition of fog water collected along the California coast. Environ. Sci. Technol. 19, 730-736. doi: $10.1021 / \mathrm{es} 00138 \mathrm{a} 013$

Jacob D.J., J.W. Munger, J.D. Waldman and M.R. Hofftmann, 1986. The $\mathrm{H}_{2} \mathrm{SO}_{4}-\mathrm{HNO}_{3}-\mathrm{NH}_{3}$ system at high humidities and in fogs: 1 . Spatial and temporal patterns in the San Joaquin Valley of California. J. Geophys. Res. 91, 1073-1088. doi: 10.1029/JD091iD01p01073

JJazcilevich D. A., A. García and E. Caetano, 2005. Locally induced surface air confluence by complex terrain and its effects on air pollution in the Valley of Mexico Atmos. Environ. 36, 2595-2605

doi: 10.1016/j.atmosenv.2005.05.046

Jiménez B.E., 2010. La contaminación Ambiental en México: causas, efectos y tecnología apropiada. LIMUSA, Mexico, 355 pp.

Joos F. and U. Baltensperger, 1991. A field study on chemistry, S(IV) oxidation rates and vertical transport during fog conditions. Atmos. Environ. 25, 217-230. doi: 10.1016/0960-1686(91)90292-F

Kabatas-Pendias D. and H. Pendias, 1992. Trace elements in soil and plants, vol. 1. CCR Press, Boca Raton, FL, $365 \mathrm{pp}$.

Kim G., R. Joseph, T. Scurdlark and M. Church, 2000. Atmospheric wet deposition of trace elements to Chesapeake and Delaware Bays. Atmos. Environ. 34, 3437-3444.

doi: 10.1016/S1352-2310(99)00371-4

Kulshrestha M., R. Sekar, D. Krishna, K. Hazarika, N. Dey and P. Rao, 2005. Deposition fluxes of chemical components of fog water at a rural site in north-east India. Tellus 57, 436-439.

doi: $10.1111 / j .1600-0889.2005 .00165 . x$

Lindberg S.E., 1982. Factors influencing trace metal, sulfate and hydrogen ion concentrations in rain. Atmos. Environ. 20, 2701-2810. doi: 10.1016/0004-6981(82)90263-3

Mat S.N., S. Hassan and M. Kamal, 2014. Environmental geochemical mapping on distribution of metal contamination in Topsoils Perlis, Malaysia. J. Med. Biol. Eng. 3, 277-281

Muselli M., D. Beysens, E. Soyeux and O. Clus, 2006. Is dew water potable? Chemical and biological analyses of dew water in Ajaccio (Corsica Island, France). J. Environ. Qual. 32, 1812-1817. doi: $10.2134 /$ jeq2005.0357

Nriagu J.O., 1996. A history of global metal pollution. Science 272, 223-224. doi: 10.1126/science.272.5259.223

Padilla G.H., 1989. Estudio analítico de la composición química de la precipitación pluvial en el Valle de México. Ms. Sc. thesis. División de estudios de Posgrado de la Facultad de Ingeniería, UNAM, Mexico.

Patel K.S., A. Tripathi, C.K. Chandrawanshi, S.G. Aggarwal, R.M. Patel, M.K. Deb, P.K. Agnihotri and V.K. Patel, 1998. Yellowish fog precipitation in central India. Proceedings of the First International Conference on Fog and Fog Collection, Vancouver, Canada, July 19-24, 309-312. 
Raga G.B., T. Castro and D. Baumgardner, 2001. The impact of mega-city pollution on local climate and implications for the regional environment México City. Atmos. Environ. 35, 1805-1811. doi: $10.1016 / \mathrm{S} 1352-2310(00) 00275-2$

Ramos O.R., R. Sepúlveda and F. Villalobos, 2003. El agua en el medio ambiente: muestreo y análisis. Plaza y Valdés Editores, Mexicali, Mexico, 210 pp.

Salazar S., J.L. Bravo and Y. Falcón, 1981. Sobre la presencia de algunos metales pesados en la atmósfera de la ciudad de México. Geofis. Int. 20, 41-54.

Schemenauer R.S. and P. Cereceda, 1992. The quality of fog water collected for domestic and agricultural use in Chile. J. Appl. Meteor. 31, 275-290.

doi: 10.1175/1520-0450(1992)031<0275:TQOFW$\mathrm{C}>2.0 . \mathrm{CO} ; 2$

SMA, 2008. Inventario de emisiones de contaminantes tóxicos de la ZMVM. Sistema de Monitoreo Atmosférico de la Ciudad de México. Available at: http:// www.sedema.df.gob.mx/flippingbook/inventario-emisiones-zmvm-toxicos2010/.
Tucker M.E., 1991. Sedimentary petrology. Backwell Science, $260 \mathrm{pp}$.

Wiersman G.B. and C.I. Davidson, 1986. Trace metals in the atmosphere of remote areas. In: Toxic metals in the atmosphere (J.O. Nriagu and C.I. Davidson, Eds.). Wiley, 201-206.

WOOD, J. M. y E. D. GOLDBERG. 1977. Impact of metals on the biosphere. In: W. Stumm. (ed.) Global chemical cycles and their alternations by man. pp. 67-95.

Wood J.M. and E.D. Goldberg, 1988. Impact of metals on the biosphere. In: Global chemical cycles and their alteration by man (W. Stumm, Ed.). Dahlem Workshop, 137-153.

WHO, 1994. Water sanitation health. World Health Organization. Available at: http://www.who.int/water_sanitation_health/dwq/GDWAN4rev1and2.pdf. 